\title{
EVALUATION OF FREQUENCY RESOURCES OF FOCL WITH THE USE OF NEW TECHNOLOGIES
}

\author{
Manko A. ${ }^{1}$, Domracheva K. ${ }^{2}$, Bokla N. ${ }^{3}$, Shestopal I. ${ }^{2}$ \\ ${ }^{1}$ Odessa National Academy of Telecommunications, Odessa, Ukraine \\ ${ }^{2}$ State University of Telecommunications, Kyiv, Ukraine \\ ${ }^{3}$ National University of Lviv Polytechnic, Lviv, Ukraine
}

\begin{abstract}
Background. Currently, communication networks are under development of high-speed transmission technology for single channel fiber optic transmission systems, along with intensive introduction of Wavelength Division Multiplexing technology. Thus there are variants of optical channels design with different transmission rate, which may differ by an order or more, e.g., in the STM-16 standard, it is $2.5 \mathrm{Gbit} / \mathrm{s}$, and STM-256 standard - 40 Gbit / s. Thus, issues arise with respect to the comparison of frequency resource in various transmission technologies that provide certain information bandwidth.

Objective. The aim of the paper is to find solutions that can increase information throughput of FOCL at constant frequency resource.

Methods. FOCL analysis with frequency multiplexing showed the feasibility of a smaller number of channels but with a higher data rate in each channel. In addition, a perspective use of soliton transmission mode to increase capacity is shown.

Results. It was shown that to improve the wavelength division information-bandwidth transmission system in a fixed wavelength band it is plactical to use a minimum number of optical channels while increasing the transmission rate in each of them.

Conclusions. The possibility to improve information throughput by increasing the number of channels limited by the transmission band of the optical amplifiers. A considerable part of the frequency resource is used for intervals between the optical channels in order to maintain the requirements for inter-channel effect and consideration of the laser frequency instability and its spectral linewidth. Thus, there is a certain margin for further increase of FOCL throughput. This can be achieved by increasing the transmission speed in each optical channel while reducing their number.
\end{abstract}

Keywords: optical channel; transmission rate; error rate; optical soliton interchannel effect; spectral width.

\section{INTRODUCTION}

In our days, for communication networks high-speed transmission technology for single-channel fiber-optic transmission systems (FOTS) is being developed, along with the introduction of intensive technologies spectral division multiplexing (SDM). [1] However, there are variants of optical channels with different transmission speeds [2], which can differ by an order or more, for example, a standard STM-16 it is $2.5 \mathrm{~Gb} / \mathrm{s}$ and a standard STM-256 - 40 Gbit / s. Also, possibilities of transmission of information by optical solitons are being investigated [2]. Thus, questions arise regarding to the comparison frequency resources of different transmission technologies that provide certain information bandwidth.

\section{EASE OF USE OF TeChNOLOGIES THAT PROVIDE HIGH THROUGHPUT OF FOCL}

Fiber-optic transmission systems are digital transmission systems using optical fiber (FO) as a medium of transmission, they emerged as the dominant PDH technology (Plesiochronous Digital Hierarchy), which was moved from copper cable to optical fiber (FO). The technology in the development of new technology has been developed into SDH - synchronous digital hierarchy technology (SDH) using standard modules. Initial transmission speed of these modules is 155 Mbit / s (STM-1) and this time increased to $40 \mathrm{Gbit} / \mathrm{s}$ per one channel.

SDH technology was initially focused on the use of FO as a medium of transmission. Further development by increasing the capacity of the communication channel faced the technological limitations on speed. Finding ways to overcome this obstacle, followed by two promising areas. One of them was linked to possible ways to further increase the transfer rate in one channel 160 and then to 640 Gbit / s. It led to the introduction of the idea of using specific pulses solitons as the carriers and the emergence of soliton networks. The second way was associated with increasing total capacity by the use of every fiber carrying multiple optical wavelengths. This led to the emergence of technology WDM - Wave Division Multiplexing technology.

A. Wave multiplexing

Along with time division multiplexing in optical communication systems is used method of wavelength division multiplexing, which is also called the wave or wavelength multiplexing [1,2]. 
The Wave Division Multiplexing method combines multiple optical carriers at different wavelengths $\lambda \mathrm{i}$ (on the passing side) and transfers the received signal $\Sigma \lambda \mathrm{i}$ one followed FO bearing division - each in its fiber. The possibility of introducing FOCL using WDM technology for communication networks has been realized with the introduction of optical amplifiers that allow carrying out reinforcement group signal in optical form without converting it into electrical form [3]. The width of the range in which to place the supporting band gain determined that for fiber optical amplifier (FOA) with fiber doped with erbium, is in the range of of $1530-1565 \mathrm{~nm}$. Thus it imposes limits on the number of channels (carriers) that can be formed within this frequency range.

In turn, the frequency carrier allocation plan has been given in Recommendation ITU G.694.1 [4]. Originally based draft standard [4] was the frequency plan with uniform channel carrier frequencies with minimum increments of $100 \mathrm{GHz}$, which was then reduced to $50 \mathrm{GHz}$. In the wavelength range from $1528.77 \mathrm{~nm}$ to $1560.61 \mathrm{~nm}$, which corresponds to the band amplification optical amplifier can be placed maximally 41 or 81 channel respectively.

Another way to increase the number of channels is a further reduction of supporting steps up to $25 \mathrm{GHz}$, and even up to $12.5 \mathrm{GHz}$. Carrier frequency (in $\mathrm{THz}$ ) can be obtained using the generalized formula:

$$
f=193,1 \pm n \times f_{s}
$$

where $f_{s}$ - step grid frequency in $\mathrm{Hz} \mathrm{T}$ and $\mathrm{n}$ - integer: $0,1, \ldots \mathrm{m}$.

Using such small steps as $12.5 \mathrm{GHz}$ requires some effort to maintain a stable frequency (wavelength) of the carrier, temperature changes of which must be within the tolerances of established standards. These tolerances for different transmission speeds and frequency step grids can be derived on the basis of total inequality (given in [4]), which must be fulfilled selecting frequency step grid $f_{s}$ :

$$
4 \Delta f \leq f_{s}-2 B
$$

where $B$ - speed transmission Gbit / s. Frequency is in $\mathrm{GHz}$. The following estimations of upper limit of tolerance for volatility carrier frequency can be obtained on the basis of formula and are shown in Table $1[2]$.
TABLE I. THE UPPER LIMIT TOLERANCE TO CARRIER FREQUENCY INSTABILITY, GHZ

\begin{tabular}{|l|r|r|r|r|}
\hline Step of frequency plan GHz & 100 & 50 & 25 & 12.5 \\
\hline $\begin{array}{l}\text { transmission speed of } \\
2.5 \mathrm{~Gb} / \mathrm{s}\end{array}$ & 23 & 11 & 5 & 1.8 \\
\hline $\begin{array}{l}\text { transmission speed of } \\
10 \mathrm{Gbit} / \mathrm{s}\end{array}$ & 20 & 7 & 1,2 & - \\
\hline $\begin{array}{l}\text { transmission speed of } \\
40 \mathrm{Gbit} / \mathrm{s}\end{array}$ & 5 & - & - & - \\
\hline
\end{tabular}

It should be noted that formula does not include the width of the spectral line laser that for small frequency steps can be essential. The main energy of the signal with pulse modulation concentrated in the main lobe of the signal [5]. Thus, we can assume that the spectrum width of single optical channel by the modulation is $\delta f_{c}=2 / \tau$, where $\tau$ - duration of modulating pulse. In applying NRZ code this ratio can be written as: $\delta f_{c}=2 B$ where $B-$ transmission speed in channel. The use of NRZ code leads to a signal broadening and thus increasing the frequency resource consuming FOCL at constant bit rates. Thus, the use of this code type in terms of saving frequency resource is not desirable.

Building a transmission system with spectral division multiplexing the value of frequency interval between $\Delta f_{c}$ channels is important, which should include a width of channel spectrum (for NRZ code is $2 B$ ) and the spectral line width of the $\Delta f$ laser should be taken into account as well. Also, we need to consider an option as the frequency instability over time $\Delta f_{\tau} \pm$, is given in [2]. Thus, the spacing between adjacent channels should be not less, than $2 B+\Delta F+2 \Delta f_{\tau}$. And this is limiting case because, for example, the formula (2) is proposed with reserve, which is dual access to the instability of the carrier frequency. With this in mind, the final value will have the form:

$$
(2 B+\Delta F+4 \Delta f \tau) \leq f_{s}
$$

In 1 the frequency range $f_{\text {max }}-f_{\text {min }}$ can accommodate $N=\left(f_{\text {max }}-f_{\text {min }}\right) \div(2 B+\Delta F+4 \Delta f \tau)$ channels, where $N$ - Integer. Losses in the frequency range between channel spacing in this case will be:

$$
\Delta f v=N\left(\Delta F+4 \Delta f_{\tau}\right)
$$

By increasing the speed rate $B$ the value of $N$ decreases and therefore reduces frequency range loss while increasing information throughput FOCL. Thus, 
at a fixed frequency resource information throughput increase can be achieved by reducing the number of channels while increasing the speed rate. In the extreme case this could be one channel with a maximum speed rate:

$$
B=\frac{f_{\max }-f_{\min }-\Delta F-4 \Delta f \tau}{2}
$$

High speed modulation is one of the most technical challenges.

In addition, when assessing the quality of transmission FOCL SCD the mutual influences between channels should be taken into account [1], which are determined by the shape of the spectral line and between the channel interval (Fig. 1).

As shown in Fig.1, due to different forms of spectral line real source of the ideal (infinitely narrow) band wavelength channel overlaps side components spectrums adjacent channels. The formula for transient noise ratios (attenuation transition) is as follows:

$$
\alpha i j=10 \lg \frac{\text { Рвви.i }}{\text { Рвпл.ij }}
$$

where $j=1 \ldots \mathrm{N}, j \neq \neq i$

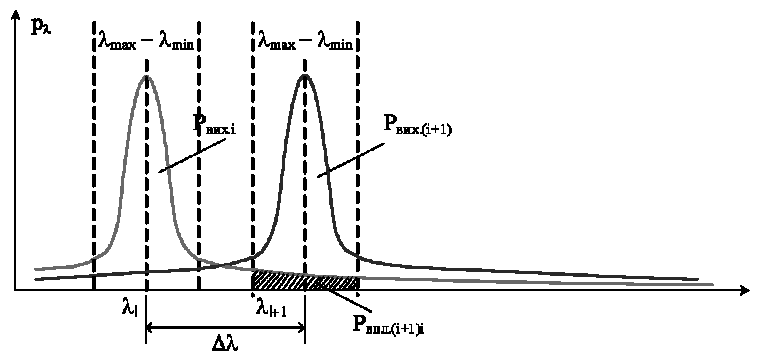

Fig. 1. The emergence of interchannel interferences in FOCL with SCD due to mutual interferences between channels

where $P_{\text {sux. } i}$ - the power of the sourcechannel radiation and (output power), $P_{\text {впл.іj }}$ - power fixed in the channel $i$ due to the influence of the channel $j, \mathrm{~N}$ - number of FOCL channels with SCD.

Then the signal / noise ratio in the channel $i$ can be evaluated from the formula:

$$
\alpha(\text { chan } . i)=10 \lg \frac{1}{\sum_{j=1}^{N} 10^{-\alpha i j \div 10}}
$$

where $j=1 \ldots \mathrm{N}, j \neq \neq i$

The presence of transient noise leads to lowering of signal / noise ratio and consequently to a deterioration in the quality of transmission. At the same time equivalent information flow transmission through the channels with higher information capacity (bit rate) allows avoiding a number of marked restriction or reduce their impact and save a frequency resource that is limited.

Additional disadvantages FOCL SCD are a nonlinear effects that are caused by the presence of a number of optical channels and increased fiber capacity [6]. Most of non-linear effects are four wave mixing, which leads to the combination of parasitic components in the signal spectrum. These components can be in bands of working channels. The range of signals propagating along the fiber with frequencies $\mathrm{f}_{1} \mathrm{f}_{2}, \mathrm{f}_{3}$ based on products of four wave mixing is shown in Fig.2 [6].

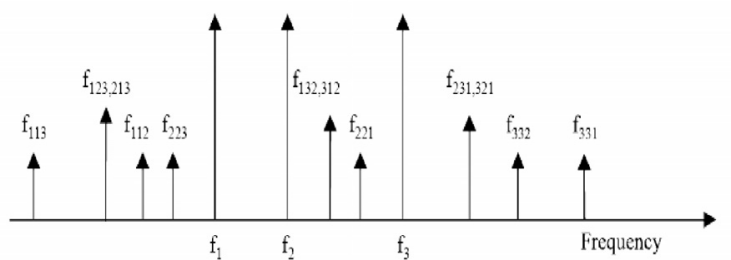

Fig. 2. Group signal spectrum given for 4-wave mixing

Total number combination of parasitical signals in the presence of $N$ of working channels is:

$$
N^{2}(N-1) \div 2
$$

Such a large number of components significantly reduces the signal / noise ratio in each channel and degrades the quality of transmission by the increase of error rate. In addition to such drawbacks as overvalued frequency resource for FOCL SCD are inherented nonlinear effects that degrade the quality of transmission.

\section{B. Optical Time Domain Multiplexing (OTDM)}

Time domain multiplexing in optical transmission lines comes together with the first optical lines. With the wave multiplexing it is used in each wave channel. The use of Wave Division Multiplexing allows increasing the amount of information to be transmitted. But information capacity and speed of information transmission - is not the same. For example, one channel for transmitting high-definition television with required bit rate (uncompressed) is $994.3 \mathrm{Mbit} / \mathrm{s}$ [7]. That is, these requirements create preconditions for the development actuality transmission systems with high speed (OTDM - Optical Tirhe Division Multiplexing). Reached at this time OTDM system speed is 40 Gbit / s (STM-256). Further increasing the transfer rate can be achieved through the performance of electronic components of FOCL like optical modulator and semiconductor devices (transistors), on which are built electronic control circuit modulation. According to [1], modulator built on Mach-Zehnder effect can provide 
order modulation rate of $75 \mathrm{~Gb} / \mathrm{s}$. Unambiguous electronic semiconductor components, the newly developed relatively new type of transistor - HEMT (High-electron-mobility transistor with high electron mobility, providing working at frequencies of the order of several hundred GHz.[8] Thus, increasing the speed of operation modulators or to develop new high-speed types in conjunction with HEMT-transistors will allow to achieve transfer rates in a wave channel in order of hundreds $\mathrm{Gb} / \mathrm{s}$.

At this time in the development and creation of OTDM components for them are being carried out. In [9] was reported the successful test of FOCL OTDM transmission at speeds of 1.28 Tbyt / s over a distance of $70 \mathrm{~km}$. In this system were used compensation dispersion (PMD and chromatic) and phase modulation. As a source of FOCL OTDM using laser synchronization modes that can achieve record-short duration optical pulse modulators as well as kits that drive pulses through the respective delay line and adder in the optical fiber.

Perhaps the relatively reasonable option at this time can be considered FOCL system with an optimal combination of WDM and OTDM. On such a system was reported in [2]. In this system at four wavelengths (ie four spectral channels) transmitted on $160 \mathrm{~Gb} / \mathrm{s}$ digital signals were generated by OTDM. Line length was $240 \mathrm{~km}$.

As for chromatic dispersion, the transfer rate increases and the impact of the broadening of pulses to transfer mode that requires the use of in-line dispersion compensator compensating fiber-based or based on optical fiber Bragg gratings. Get rid of this defect is still possible using soliton transfer mode.

\section{Soliton transfer mode for FOCL}

Further research for the speed rate increase led to the practical implementation of special pulses - solitons as the carriers and the emergence of soliton networks.

In conventional OTDM FOCL the main limiting factor for the speed rate is the pulse broadening due to group velocity dispersion and actions of certain nonlinear effects. Optical solitons - wave packets that are excited by laser light source in the fiber at the joint action of the dispersion and nonlinear effects in the anomalous dispersion. Solitons can be distributed in the optical fiber over long distances (in order of several thousand kilometers) with little or no distortion of the shape and stored when dealing with each other, restoring direction, speed and amplitude, i.e. showing property characteristic of particles [10]. Features of formation of solitons allow using in soliton transmission lines of RZ code, and it increases the width of optical channel compared with NRZ code.
Increasing the bit rate requires the reduction of soliton pulse duration, which is approximately 4 ps for the soliton. To this end, FOCL soliton uses soliton pulses compression. The first and second spectral windows transparency uses compressors fiber grid. In the third window compression is performed due to the choice of higher order solitons. It provides compression duration of pulses in 8-12 times [2]. In the second spectral window transparency it is possible to use both methods providing large (up to 5000) rates and the compression ratio pulses of several femtoseconds. Thus, there is a very strong potential for growth speed transmission soliton networks. Also, it should be noted that the width and spectrum of the optical signal are being increased.

Soliton lines can be used for increasing the length of regeneration station transmission speeds up to order of 160 Gbit / s (STM-1024 level), or to transmit information over very long distances (several thousand kilometers) without regenerators. With resultant loss of soliton peak power can be compensated using optical amplifiers (op-amp). Moreover amplifier restores the soliton as a physical nature, then salt ton pulse is compressed to the original width. Given the fact that the reinforcement distributed along the length lightguide, the pumping radiation having shorter wavelength can be periodically injected into fiber at several locations in the direction opposite to the proliferation of solitons. The length of this line can range from several thousand to several tens of thousands of kilometers [2].

Test on soliton lines confirmed high reliability of soliton systems and their resistance to high values of polarization dispersion mode (PDM), unlike conventional optical transmission systems, where the same values PDM would be critical even at the speed of $10 \mathrm{Gbit} / \mathrm{s}$. Thus, these tests confirm the future of soliton networks, used in existing systems, WDM, for example, from 32-64 channels, each in soliton regime at $40 \mathrm{Gbit} / \mathrm{s}$ to realize the channel capacity of 1.6 Tbit $2.56 /$ with.

\section{CONCLUSION}

Fiber-optic transport systems have the highest limit bandwidth compared to other transmission systems. Among them FOCL SDM broaden its distribution with the ability to accommodate a number of spectral channels at certain wavelengths. The possibility of throughput increased by enhancing the number of channels is limited by bandwidth of optical amplifiers. A substantial portion of the frequency resource is to provide spacing between optical channels to maintain a link between the requirements for interchannel interference and laser frequency instability and its spectral line width. Thus, there is a margin for further 
throughput increase of FOCL. This can be achieved by increasing the transfer rate in each optical channel while reducing their number. In this case, NRZ code is used for the transmission as one that provides the minimum width of the spectrum of the optical channel. Thus, the best way to build transmission systems with high information capacity in a limited frequency range is to combine technology with high-speed WDM technology OTDM.

Quite effective solution that can even double the information capacity of the system at a constant frequency resource is an additional polarization multiplexing, where two optical channels are transmitted with orthogonal polarization in the same bandwidth [11].

Soliton transmission mode [10] is under further investigation, during which we can expect determination of its effectiveness used in high-speed optical systems.

\section{REFERENCES}

[1] Roger L. Freeman. Fiber-Optic Systems for Telecommunications, 2002, 416 p.

[2] S. Dmitriev, N. Slepov. Fiber-optic apparatus: modern trends and prospects. $2^{\text {nd }}$ Vol., "Fiber-optic apparatus", 2005, $576 \mathrm{p}$

[3] N. Slepov. Modern technologies of digital fiber optic communication networks, $2^{\text {nd }}$ Vol., 2003, 468 p.

[4] ITU-T Recommendation G.694.1 (06/02) Spectral grids for WDM applications: DWDM frequency grid.

[5] W. Tomasi. Electronic Communications System, 2007, $1360 \mathrm{p}$.

[6] ITU-T Recommendation G.663 Application Related Aspects of Optical Fiber Amplifier Devices and Subsystem

[7] S. Li. Semiconductor Physical Electronics. $2^{\text {nd }}$ Edition. Springer, 2006. $708 \mathrm{p}$.

[8] Yamamoto T., Tamura KR 1,28 Tbit/c - $70 \mathrm{~km}$ OTDM transmission with a phase third and fourth-order simultaneously dispersion compensation with a phase modulation. Electronics Letters. 2000, vol. 36 , \#24, pp. 2027-2028.

[9] G. Agraval. Non-linear fiber optics, 1996, $324 \mathrm{p}$.

[10] O. Sklyarov. Fiber-optic networks and communication systems. $2^{\text {nd }}$ Vol., 2010, 272 p. 


\section{Манько О.О., Домрачева К.О., Бокла Н.І., Шестопал Е.О.}

\section{Оцінка частотного ресурсу ВОСП при використані нових технологій}

Проблематика. В даний час для мереж зв'язку проводяться розробки високошвидкісних технологій передачі для одноканальних волоконно-оптичних систем передачі наряду з інтенсивним впровадженням технології спектрального поділу каналів. При цьому існують варіанти побудови оптичних каналів з різною швидкістю передачі, яка може відрізнятися на порядок і більше, наприклад, в стандарті STM-16 вона становить 2,5 Гбіт/с, а в стандарті STM-256 - 40 Гбіт/с. Крім того, досліджуються можливості передачі інформації за допомогою оптичних солітонів. Таким чином, виникають питання щодо порівняння частотного ресурсу різних технологій передачі, які забезпечують певну інформаційно-пропускну здатність.

Мета досліджень. Метою даної роботи є пошук рішень, які можуть збільшити інформаційно-пропускну здатність ВОСП при незмінному частотному ресурсі.

Методика реалізації. Аналіз ВОСП з частотним мультиплексуванням дав змогу зробити висновок про доцільність використання меншої кількості каналів але з більшою швидкістю передачі даних в кожному каналі. Крім того, показано перспективне використання солітоного режиму передачі для збільшення пропускної здатності.

Результатидосліджень. Показано, що для підвищення інформаційно-пропускної здатності системи передачі зі спектральним поділом каналів у фіксованому діапазоні довжин хвиль доцільно застосовувати меншу кількість оптичних каналів при одночасному збільшенні швидкості передачі в кожному з них.

Висновки. Можливість підвищення інформаційно-пропускної здатності за рахунок збільшення кількості каналів обмежується смугою пропускання оптичних підсилювачів. При цьому значна частина частотного ресурсу йде на забезпечення інтервалів між оптичними каналами з метою підтримання вимог щодо міжканального впливу та обліку нестабільності частот лазера та ширини його спектральної лінії. Таким чином, існує певний запас подальшого нарощування інформаційно-пропускної здатності ВОСП. Досягти це можна за рахунок збільшення швидкості передачі в кожному оптичному каналі при одночасному зменшенні їх кількості.

Ключові слова: оптичний канал; швидкість передачі; коефіцієнт помилок; оптичний солітон; міжканальний вплив; ширина спектра.

\section{Манько А.А., Домрачева Е.А., Бокла Н.И., Шестопал Е.А.}

Оценка частотного ресурса ВОСП при использовании новых технологий

Проблематика. В настоящее время для сетей связи проводится разработка высокоскоростных технологий передачи для одноканальных волоконно-оптических систем передачи наряду с интенсивным внедрением технологии спектрального разделения каналов. При этом существуют варианты построения оптических каналов с разной скоростью передачи, которая может отличаться на порядок и более, например, в стандарте STM-16 она составляет 2,5 Гбит / с, а в стандарте STM-256 - 40 Гбит / с . Кроме того, исследуются возможности передачи информации с помощью оптических солитонов . Таким образом, возникают вопросы относительно сравнения частотного ресурса различных технологий передачи, которые обеспечивают определенную информационно-пропускную способность.

Цель исследований. Целью данной работы является поиск решений, которые могут увеличить информационнопропускную способность ВОСП при неизменном частотном ресурсе.

Методика реализации. Анализ ВОСП с частотным мультиплексированием позволил сделать вывод о целесообразности использования меньшего количества каналов но с большей скоростью передачи данных в каждом канале. Кроме того, показано перспективное использование солитонного режима передачи для увеличения пропускной способности.

Результаты исследования. Показано, что для повышения информационно-пропускной способности системы передачи с спектральным разделением каналов в фиксированном диапазоне длин волн целесообразно применять меньшее количество оптических каналов при одновременном увеличении скорости передачи в каждом из них.

Выводы. Возможность повышения информационно-пропускной способности за счет увеличения количества каналов ограничивается полосой пропускания оптических усилителей. При этом значительная часть частотного ресурса идет на обеспечение интервалов между оптическими каналами с целью поддержания требований относительно меж канального влияния и учета нестабильности частоты лазера и ширины его спектральной линии. Таким образом, существует определенный запас по дальнейшему наращиванию информационно-пропускной способности ВОСП. Достичь этого можно за счет увеличения скорости передачи в каждом оптическом канале при одновременном уменьшении их количества.

Ключевые слова: оптический канал; скорость передачи; коэффициент ошибок; оптический солитон; межканальное влияние; ширина спектра. 